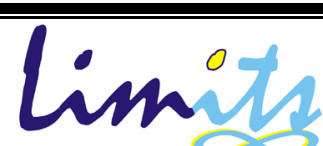

Limits: Journal of Mathematics and Its Applications

E-ISSN: 2579-8936

P-ISSN: 1829-605X

Vol. 18, No. 2, Nopember 2021, 142-153

DOI: http://dx.doi.org/10.12962/limits.v18i2.7774

\title{
Model Matematika SEAR dengan Memperhatikan Faktor Migrasi Terinfeksi untuk Kasus COVID-19 di Indonesia
}

\author{
E. Andry Dwi Kurniawan, Fatmawati*, Aprilia Dianpermatasari \\ Departemen Matematika, Fakultas Sains dan Teknologi, Universitas Airlangga, Surabaya, Indonesia \\ e-mail:fatmawati@fst.unair.ac.id
}

Diajukan: 23 September 2020, Diperbaiki: 27 September 2021, Diterima: 27 Oktober 2021

\begin{abstract}
Abstrak
Dalam paper ini, dikonstruksi sebuah model matematika SEAR (Susceptible, Exposed, Acute, Recovery) penyebaran COVID-19 dengan memperhatikan faktor migrasi yang terinfeksi. Estimasi parameter dari model matematika SEAR dilakukan berdasarkan data perkembangan penyebaran COVID19 di Indonesia. Dari hasil estimasi diperoleh nilai basic reproduction number $\left(R_{0}\right)$ untuk mengetahui laju penyebaran COVID-19 di Indonesia. Berdasarkan hasil simulasi numerik terlihat bahwa faktor migrasi memberikan pengaruh yang signifikan terhadap penyebaran kasus COVID-19 di Indonesia.

Kata Kunci: Model matematika, Estimasi parameter, COVID-19, Coronavirus, Faktor migrasi.

Abstract

In this paper, we constructed a mathematical model SEAR (susceptible exposed acute recovery) spread of COVID-19 within migration factor. The parameters estimation of the SEAR mathematical model are considered by using the reported data of COVID-19 in Indonesia. We also estimated the value of the basic reproduction number $\left(R_{0}\right)$ to determine the rate of spread of COVID-19 in Indonesia. Based on the result of numerical simulation, we can conclude that the migration factor gives a significant effect on to spread of COVID-19 in Indonesia.
\end{abstract}

Keywords: Mathematical model, parameter estimation, COVID-19, Coronavirus, migration factor.

\section{Pendahuluan}

Coronavirus merupakan keluarga besar virus yang menyebabkan penyakit pada manusia dan hewan. Pada manusia biasanya menyebabkan penyakit infeksi saluran pernapasan, mulai dari flu biasa hingga penyakit yang serius seperti Middle East Respiratory Syndrome (MERS) dan Sindrom Pernafasan Akut Berat/Severe Acute Respiratory Syndrome (SARS). Coronavirus jenis baru pada manusia ditemukan sejak kejadian luar biasa yang pertama kali muncul di Wuhan Cina, pada Desember 2019. Kemudian virus tersebut diberi nama Severe Acute Respiratory Syndrome Coronavirus 2 (SARS-COV2) dan menyebabkan penyakit Coronavirus Disease-2019 (COVID19) yang menyebar keseluruh dunia dengan sangat cepat [1].

Penyebaran COVID-19 pertama kali di Indonesia diketahui sejak dilaporkannya kasus positif pada tanggal 2 Maret 2020. Pada tanggal 28 Mei 2020, Indonesia telah mencatat sebanyak 24,538 kasus positif COVID-19 [2]. Berbagai upaya telah dilakukan pemerintah untuk menekan 
angka kasus positif di Indonesia, mulai dari kebijakan pembatasan sosial berskala besar (PSBB) hingga pengendalian transportasi. Banyaknya masyarakat yang melanggar kebijakan pemerintah tersebut membuat upaya pemerintah seakan tidak memberikan dampak apapun terhadap angka kasus positif di Indonesia [3].

Menurut survei yang dilakukan oleh LIPI (Pusat Penelitian Kependudukan), terdapat 43,78\% dari total responden memiliki rencana untuk mudik ke kampung halaman. Berdasarkan penelitian tersebut, LIPI menyimpulkan bahwa di tengah situasi pandemi COVID-19, masih banyak penduduk yang merencanakan untuk melakukan perjalanan jarak jauh atau mudik pada saat libur Hari Raya Idul Fitri [4]. Saat pemerintah telah melarang masyarakat untuk mudik dan bepergian di tengah pandemi COVID-19, sejumlah perantau yang tidak memiliki pekerjaan dan kesulitan ekonomi lebih memilih pulang kampung dengan alasan ada harapan ekonomi, dekat dengan keluarga, dan menghindari risiko tertular. Hal tersebut menjadi salah satu penyebab meningkatnya jumlah kasus positif COVID-19 di Indonesia.

Kedatangan para pekerja migran dari luar negeri menjadi salah satu penyebab yang ikut memperburuk kasus COVID-19 di Indonesia. Sebanyak 591 warga negara Indonesia (WNI) yang bekerja di luar negeri dinyatakan positif corona [5]. Hal ini dapat mempengaruhi laju penyebaran pandemik COVID-19 di Indonesia semakin tidak terkendali. Orang yang bermigrasi dapat menjadi agen pembawa virus sehingga dapat menyebarkan penyakit ke wilayah baru.

Beberapa peneliti di bidang matematika telah memodelkan kasus penyebaran pandemi COVID-19 di Indonesia, diantaranya Nuning dkk yang menggunakan Richard's Curve and Least Square Method untuk merepresentasikan dinamika penderita COVID-19 di Indonesia [6]. Susanto menggunakan model SI (Susceptible, Infectious) untuk menggambarkan penyebaran COVID-19 dengan asumsi adanya lockdown namun masyarakat tetap beraktifitas seperti biasa [7]. Model deterministik lainnya yang diformulasikan untuk menganalisis wabah COVID-19 di Indonesia juga bisa dilihat pada [8]-[10]dan beberapa referensi lainnya.

Wang dkk (2010), memperkenalkan model SEIR (Susceptible, Expose, Infectious, Recovery) yang menggambarkan penyebaran penyakit yang dipengaruhi oleh adanya faktor migrasi [11]. Dengan menggunakan acuan model SEIR (Susceptible, Expose, Infectious, Recovery) pada [11], penulis merepresentasikan model matematika penyebaran COVID-19 dengan memperhatikan faktor migrasi terinfeksi. Tujuan dari penelitian ini adalah untuk melakukan estimasi parameter dan mengetahui hasil simulasi pada model matematika SEAR (Susceptible, Exposed, Acute, Recovery) penyebaran COVID-19 dengan memperhatikan faktor migrasi yang terinfeksi. 


\section{Model Matematika}

Model matematika SEAR dengan memperhatikan faktor migrasi terinfeksi untuk kasus penyebaran COVID-19 di Indonesia yang dibahas pada paper ini diperoleh dari hasil modifikasi model matematika yang ditulis oleh Wang dkk (2010) [11].

Adapun asumsi-asumsi dalam model matematika SEAR penyebaran COVID-19 di Indonesia sebagai berikut:

1. Populasi terbagi menjadi 4 kompartemen yaitu $S(t)$ subpopulasi individu sehat dan rentan disebut juga Susceptible, $E(t)$ subpopulasi individu dalam masa inkubasi/laten disebut juga Exposed, $A(t)$ subpopulasi individu positif COVID-19 disebut juga Acute dan $R(t)$ subpopulasi individu sembuh disebut juga Recovery.

2. Semua individu yang lahir masuk ke dalam subpopulasi Susceptible dan setiap individu yang mati dari setiap subpopulasi mempunyai laju proporsional dengan jumlah individu pada masing-masing subpopulasi.

3. Individu yang telah sembuh dari COVID-19 mengalami kekebalan yang permanen. Dengan demikian, individu yang telah sembuh tidak akan masuk kedalam subpopulasi Susceptible kembali.

Berikut notasi dan definisi dari masing-masing variabel dan parameter pada model matematika SEAR penyebaran COVID-19 di Indonesia.

Tabel 1. Variabel Model Matematika SEAR Penyebaran COVID-19 di Indonesia

\begin{tabular}{cll}
\hline Variabel & Keterangan & Satuan \\
\hline$S(t)$ & Jumlah individu sehat yang rentan pada saat $t$ & Orang \\
$E(t)$ & Jumlah individu dalam masa inkubasi/laten pada saat $t$ & Orang \\
$A(t)$ & Jumlah individu positif COVID-19 pada saat $t$ & Orang \\
$R(t)$ & Jumlah individu yang sembuh dari COVID-19 pada saat $t$ & Orang \\
\hline
\end{tabular}

Parameter yang digunakan pada model matematika dalam paper ini ditunjukkan pada tabel sebagai berikut:

Tabel 2. Parameter Model Matematika SEAR Penyebaran COVID-19 di Indonesia

\begin{tabular}{cll}
\hline Parameter & Keterangan & Satuan \\
\hline$\mu$ & Laju kematian alami & (orang.hari) ${ }^{-1}$ \\
$\beta$ & Laju transmisi infeksi COVID-19 & (orang.hari) ${ }^{-1}$ \\
$\varepsilon$ & Laju perubahan individu laten menjadi individu positif & (orang.hari) $)^{-1}$ \\
$\alpha$ & Laju kematian oleh COVID-19 & (orang.hari) $)^{-1}$ \\
$\gamma$ & Laju penyembuhan individu positif COVID-19 & (orang.hari) $^{-1}$ \\
$\Lambda$ & Laju rekruitmen individu rentan & orang.(hari)
\end{tabular}




\begin{tabular}{cll}
\hline Parameter & Keterangan & Satuan \\
\hline$p$ & Laju migrasi individu carrier & (orang.hari) $^{-1}$ \\
\hline
\end{tabular}

Selanjutnya untuk memudahkan penulisan maka notasi $S(t), E(t), A(t)$ dan $R(t)$ berturutturut ditulis dengan $S, E, A$ dan $R$. Secara biologis, variabel yang digunakan menyatakan populasi pada waktu $t$ tertentu sehingga semua variabel bernilai non negatif atau dapat dituliskan dalam pertidaksamaan $S, E, A, R \geq 0$, dengan $N=S+E+A+R$. Selain itu, seluruh parameter diasumsikan bernilai positif sebab merupakan besaran yang menyatakan laju dan dapat dituliskan sebagai $\mu, \beta, \varepsilon, \alpha, \gamma, \Lambda, p>0$.

Berdasarkan asumsi dan pendefinisian variabel serta parameter yang berturut-turut diberikan pada Tabel 1 dan 2, dibentuk diagram transmisi seperti berikut

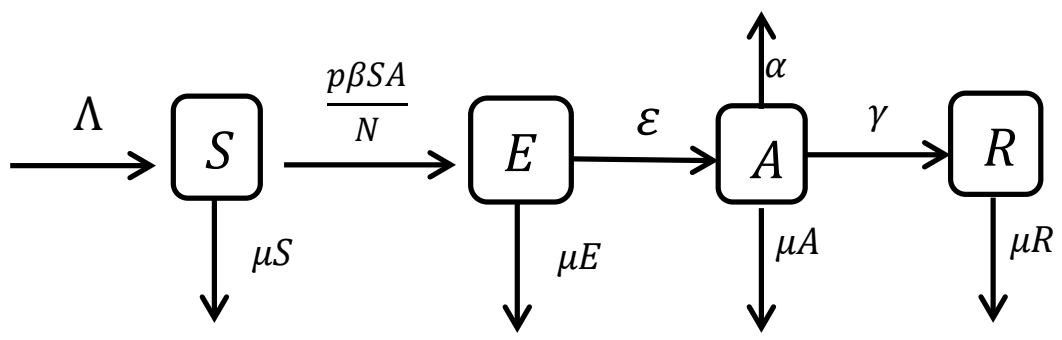

Gambar 1. Diagram Transmisi Model Matematika SEAR Penyebaran COVID-19 di Indonesia

Berdasarkan diagram transmisi pada Gambar 1, dapat diformulasikan model matematika SEAR penyebaran COVID-19 di Indonesia yang berbentuk sistem persamaan diferensial biasa atau sistem dinamik sebagai berikut:

$\frac{d S}{d t}=\Lambda-\frac{p \beta S A}{N}-\mu S$

$\frac{d E}{d t}=\frac{p \beta S A}{N}-(\mu+\varepsilon) E$

$\frac{d A}{d t}=\varepsilon E-(\alpha+\gamma+\mu) A$

$\frac{d R}{d t}=\gamma A-\mu R$

\subsection{Estimasi Parameter}

Dalam menentukan estimasi parameter akan diasumsikan bahwa laju migrasi yang terjadi dalam keadaan normal, hal ini berarti parameter $p$ bernilai satu $(p=1)$. Dengan demikian, parameter yang diperoleh dari hasil estimasi tidak akan menampilkan nilai parameter berupa faktor migrasi tersebut. Faktor migrasi dalam paper ini akan diuji pengaruhnya terhadap dinamika penyebaran kasus COVID-19 di Indonesia dengan cara memberikan dua nilai berbeda saat dilakukan simulasi, yaitu nilai yang menunjukkan terjadinya keadaan migrasi gelombang rendah dan gelombang tinggi. 
Untuk selanjutnya, model matematika yang akan digunakan untuk diestimasi parameternya adalah sebagai berikut:

$\frac{d S}{d t}=\Lambda-\frac{\beta S A}{N}-\mu S$

$\frac{d E}{d t}=\frac{\beta S A}{N}-(\mu+\varepsilon) E$

$\frac{d A}{d t}=\varepsilon E-(\alpha+\gamma+\mu) A$

$\frac{d R}{d t}=\gamma A-\mu R$

Parameter laju kematian alami telah ditentukan nilainya yaitu dari invers angka harapan hidup pada tahun 2019 sebesar 71.34 [12]. Dengan demikian, laju kematian alami $\mu=\frac{1}{(71,34 \times 365)}=$ 0.0000384037 .

Berdasarkan model di atas, nilai parameter pada model yang belum diketahui berjumlah 5 parameter yaitu $\beta, \varepsilon, \alpha, \gamma$, dan $\Lambda$. Parameter-parameter ini yang akan diestimasi nilainya menggunakan algoritma genetika.

Data yang digunakan untuk melakukan estimasi parameter dari model matematika SEIR untuk kasus COVID-19 di Indonesia adalah data jumlah kasus per hari dari masing-masing variabel dari 15 April 2020 sampai 24 Agustus 2020. Data secara lengkap disajikan pada Tabel 3.

Tabel 3. Data Jumlah Kasus Harian COVID-19 di Indonesia

\begin{tabular}{lclll}
\hline Tanggal & $\begin{array}{c}\text { Jumlah Kasus } \\
\text { Sehat }\end{array}$ & $\begin{array}{c}\text { Jumlah Kasus } \\
\text { Laten }\end{array}$ & $\begin{array}{c}\text { Jumlah Kasus } \\
\text { Positif }\end{array}$ & $\begin{array}{c}\text { Jumlah Kasus } \\
\text { Sembuh }\end{array}$ \\
\hline 15 April 2020 & 269813254 & 181164 & 5136 & 446 \\
16 April 2020 & 269812617 & 181319 & 5516 & 548 \\
17 April 2020 & 269807128 & 186342 & 5923 & 607 \\
18 April 2020 & 269803798 & 189323 & 6248 & 631 \\
19 April 2020 & 269798210 & 194529 & 6575 & 686 \\
20 April 2020 & 269794380 & 198113 & 6760 & 747 \\
21 April 2020 & 269788930 & 203093 & 7135 & 842 \\
22 April 2020 & 269780344 & 211325 & 7418 & 913 \\
23 April 2020 & 269777034 & 214231 & 7775 & 960 \\
24 April 2020 & 269774535 & 216252 & 8211 & 1002 \\
25 April 2020 & 269764356 & 225995 & 8607 & 1042 \\
26 April 2020 & 269761323 & 228688 & 8882 & 1107 \\
27 April 2020 & 269759567 & 230186 & 9096 & 1151 \\
28 April 2020 & 269755163 & 234072 & 9511 & 1254 \\
$\vdots$ & $\vdots$ & $\vdots$ & $\vdots$ & $\vdots$ \\
22 Agustus 2020 & 263704203 & 6039101 & 151498 & 105198
\end{tabular}




\begin{tabular}{lclll}
\hline Tanggal & $\begin{array}{c}\text { Jumlah Kasus } \\
\text { Sehat }\end{array}$ & $\begin{array}{c}\text { Jumlah Kasus } \\
\text { Laten }\end{array}$ & $\begin{array}{c}\text { Jumlah Kasus } \\
\text { Positif }\end{array}$ & $\begin{array}{c}\text { Jumlah Kasus } \\
\text { Sembuh }\end{array}$ \\
\hline 23 Agustus 2020 & 263624342 & 6114623 & 153535 & 107500 \\
24 Agustus 2020 & 263542160 & 6191368 & 155412 & 111060 \\
\hline
\end{tabular}

Sumber : Kementerian Kesehatan Indonesia [2]

Proses estimasi parameter dalam model matematika SEIR untuk kasus COVID-19 di Indonesia terdiri dari 5 parameter (gen). Hasil yang akan diambil dari proses estimasi parameter adalah nilai-nilai parameter yang menyebabkan nilai hasil perhitungan mmemiliki selisih terkecil dengan data riil. Nilai parameter yang akan dipilih yaitu jika memiliki nilai e (error) yang didefinisikan pada persamaan (3) memiliki nilai minimal dari semua percobaan yang telah dilakukan. Persamaan (3) dipilih sebagai fungsi tujuan yang akan digunakan dalam program. Fungsi tujuan yang akan digunakan adalah sebagai berikut:

$$
e=\frac{1}{4 n} \sum_{i=1}^{n}\left[\left|\frac{w_{i}-w_{i}^{*}}{w_{i}{ }^{*}}\right|+\left|\frac{x_{i}-x_{i}{ }^{*}}{x_{i}{ }^{*}}\right|+\left|\frac{y_{i}-y_{i}{ }^{*}}{y_{i}{ }^{*}}\right|+\left|\frac{z_{i}-z_{i}^{*}}{z_{i}{ }^{*}}\right|\right]
$$

dengan $n$ adalah banyaknya data, $w_{i}{ }^{*}, x_{i}{ }^{*}, y_{i}{ }^{*}$, dan $z_{i}{ }^{*}$ adalah jumlah kasus ke- $i$ dari data riil untuk setiap variabel. Selanjutnya, $w_{i}, x_{i}, y_{i}$, dan $z_{i}$ adalah jumlah kasus ke- $i$ yang diperoleh dari solusi model, dengan $i=1,2,3, \ldots, n$. Dalam program di penelitian ini, terdapat jumlah parameter ( $n v a r)$, jumlah populasi awal (npop), probabilitas mutasi, jumlah generasi dan probabilitas pindah silang yang terlebih dahulu harus ditentukan nilainya.

Parameter nvar menyatakan jumlah parameter yang akan diestimasi. Sedangkan nilai parameter прор tidak ditentukan secara spesifik, sehingga perlu dicari nilainya yang memberikan hasi yang mendekati optimum. Pada penelitian ini menggunakan nрор sebesar 100, karena semakin besar nрор maka akan membuat waktu yang dibutuhkan prohram untuk memproses perhitungan semakin besar.

Selanjutnya, untuk keperluan praktis, probabilitas pindah silang dipilih sebesar 0.5 [13]. Sedangkan nilai parameter probabilitas mutasi akan menggunakan lima macam nilai yaitu 0.025 , $0.05,0.125,0.25$ dan 0.5 agar mendapatkan hasil yang mendekati optimum. Setiap nilai dari kelima macam nilai probabilitas mutasi tersebut akan dilakukan tujuh kali percobaan. Nilai dari probabilitas mutasi diubah-ubah karena proses mutasi merupakan eksplorasi ruang solusi [14].

Dalam kode program juga terdapat jumlah generasi yang harus ditentukan nilainya. Semakin banyak generasi maka semakin banyak waktu yang dibutuhkan program untuk memproses perhitungan, sehingga dalam penelitian ini akan digunakan jumlah generasi sebanyak 100 generasi. Dari percobaan dengan nilai iterasi sebesar 100, diperoleh nilai fungsi biaya yang cenderung bernilai sama menuju iterasi ke-100. 
Hasil estimasi parameter yang digunakan adalah nilai error minimal dari tujuh kali percobaan pada setiap probabilitas mutasi. Berikut akan disajikan nilai error minimal hasil estimasi parameter yang dilakukan sebanyak tujuh kali percobaan pada setiap probabilitas mutasi.

Tabel 4. Hasil Estimasi Parameter dengan Tujuh Kali Percobaan untuk Error Minimal

\begin{tabular}{lrlllll}
\hline \multirow{2}{*}{ No } & \multirow{2}{*}{ Parameter } & \multicolumn{2}{l}{ Probabilitas Mutasi } & $\mathbf{0}$ & \multicolumn{1}{l}{} \\
& & $\mathbf{0 . 0 2 5}$ & $\mathbf{0 . 0 5}$ & $\mathbf{0 . 1 2 5}$ & $\mathbf{0 . 2 5}$ & $\mathbf{0 . 5}$ \\
\hline 1 & $\beta$ & 0.57029 & 0.71804 & 0.99102 & 0.82307 & 0.73038 \\
2 & $\varepsilon$ & 0.001924 & 0.0015031 & 0.0083116 & 0.0016138 & 0.001462 \\
3 & $\alpha$ & $7.2217 \times 10^{-6}$ & $9.4957 \times 10^{-6}$ & 0.18169 & $1.6138 \times 10^{-6}$ & $7.3038 \times 10^{-6}$ \\
4 & $\gamma$ & 0.010457 & 0.0097531 & 0.012122 & 0.016138 & 0.0073038 \\
5 & $\Lambda$ & 233.9332 & 1942.577 & 552.2431 & 322.7688 & 1460.7661 \\
& \multirow{2}{*}{ Error } & 0.15628 & 0.18052 & 0.1317 & 0.15189 & 0.21112 \\
\hline
\end{tabular}

Berdasarkan Tabel 4 dapat diamati bahwa nilai estimasi parameter dengan error terkecil adalah ketika nilai probabilitas mutasi sebesar 0.125 , dengan nilai error terkecil yaitu 0.1317 atau sebesar $13.17 \%$ Nilai masing-masing parameter dari hasil estimasi disajikan pada Tabel 5 berikut.

Tabel 5. Nilai Parameter Hasil Estimasi

\begin{tabular}{rcll}
\hline No & Parameter & Nilai Parameter & Satuan \\
\hline 1. & $\beta$ & 0.99102 & (orang.hari) $^{-1}$ \\
2. & $\varepsilon$ & 0.0083116 & (orang.hari) $^{-1}$ \\
3. & $\alpha$ & 0.18169 & (orang.hari) $^{-1}$ \\
4. & $\gamma$ & 0.012122 & (orang.hari) $^{-1}$ \\
5. & $\Lambda$ & 552.2431 & orang.(hari) \\
\hline
\end{tabular}

Hasil simulasi perbandingan antara penyelesaian persamaan diferensial dengan data riil disajikan pada Gambar 2.

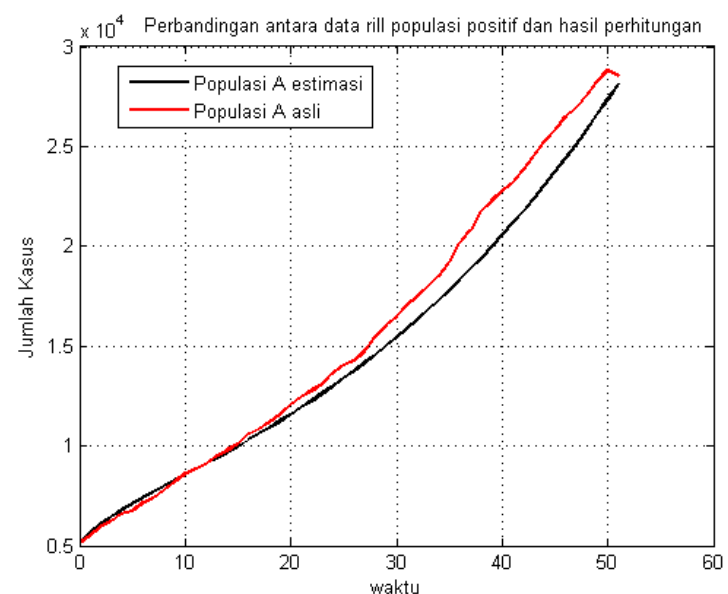

(a)

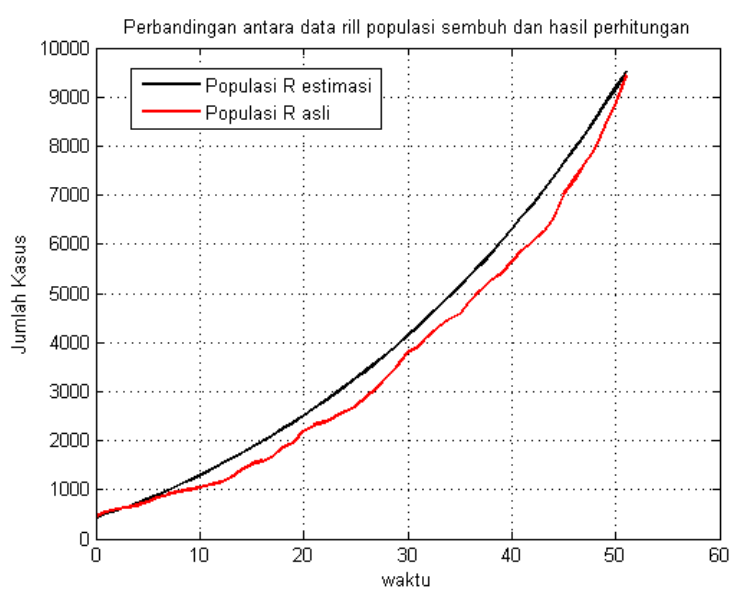

(b)

Gambar 2. Perbandingan Jumlah Kasus Positif (a) dan Sembuh (b) dengan Simulasi Model 


\subsection{Basic Reproduction Number $\left(R_{0}\right)$}

Selanjutnya, akan ditentukan nilai dari Basic Reproduction Number atau $\left(R_{0}\right)$ dari titik setimbang non endemik. Parameter $\left(R_{0}\right)$ ini akan ditentukan untuk mengetahui ambang batas suatu keadaan yang menunjukkan bahwa suatu penyakit mengalami keadaan ada penyebaran atau tidak. Metode yang digunakan adalah dengan NGM (Next Generation Matrix) melalui pendekatan Driessche dan Watmough (2002) [15]. Berikut langkah-langkah dalam menentukan $\left(R_{0}\right)$ :

1. Akan dicari terlebih dahulu titik setimbang non endemik (bebas penyakit). Keadaan ini terjadi ketika populasi individu yang positifCOVID-19 bernilai nol $(A=0)$ sehingga menyebabkan $(E=R=0)$.

Dengan demikian diperoleh $S=\frac{\Lambda}{\mu}$. Misalkan titik setimbang non endemik dinyatakan sebagai $E_{0}=$ $(S, E, A, R)$, maka titik setimbang $E_{0}$ dari model matematika SEAR penyebaran COVID-19 di Indonesia adalah $E_{0}=\left(\frac{\Lambda}{\mu}, 0,0,0\right)$.

2. Misalkan $\frac{d x}{d t}=\mathcal{F}(x)-\mathcal{Z}(x)$, dengan $\mathcal{F}(x)$ menyatakan matriks transmisi, yang elemennya berisi populasi yang terinfeksi akibat interaksi dengan $A$ sedangkan $Z(x)$ menyatakan matriks transisi, matriks yang berisi populasi yang terinfeksi yang tidak memuat suku interaksi penularan

$\mathcal{F}(x)=\left(\begin{array}{c}\frac{\beta S A}{N} \\ 0\end{array}\right) \operatorname{dan} Z(x)=\left(\begin{array}{c}(\mu+\varepsilon) E \\ \alpha+\gamma+\mu-\varepsilon E\end{array}\right)$

3. Misalkan $\mathbb{F}$ dan $\mathbb{Z}$ adalah matriks Jacobian dari $\mathcal{F}(x)$ dan $Z(x)$ yang telah disubsitusikan titik setimbang $E_{0}$, dengan demikian diperoleh

$\mathbb{F}=\left(\begin{array}{cc}0 & \beta \\ 0 & 0\end{array}\right)$

$\mathbb{Z}=\left(\begin{array}{cc}\mu+\varepsilon & 0 \\ -\varepsilon & \alpha+\gamma+\mu\end{array}\right)$

$\mathbb{Z}^{-1}=\frac{1}{c}\left(\begin{array}{cc}\alpha+\gamma+\mu & 0 \\ \varepsilon & \mu+\varepsilon\end{array}\right)$ dengan $c=(\mu+\varepsilon)(\alpha+\gamma+\mu)$

4. Misalkan $\mathcal{R}=F^{-1}$, Parameter $R_{0}$ diperoleh dengan menentukan nilai eigen terbesar dari matriks $\mathcal{R}$ atau dapat dinyatakan dengan $R_{0}=\eta(\mathcal{R})$ sehingga didapatkan

$\mathcal{R}=\mathbb{F} \mathbb{Z}^{-1}$

$\mathcal{R}=\left(\begin{array}{cc}\frac{\beta \varepsilon}{C} & \frac{\beta}{\alpha+\gamma+\mu} \\ 0 & 0\end{array}\right)$ dengan $c=(\mu+\varepsilon)(\alpha+\gamma+\mu)$

Parameter $R_{0}$ merupakan nilai eigen terbesar dari matriks $\mathcal{R}=\mathbb{F} \mathbb{Z}^{-1}$, sehingga dapat diperoleh $R_{0}$ adalah sebagai berikut

$$
R_{0}=\frac{\beta \varepsilon}{(\mu+\varepsilon)(\alpha+\gamma+\mu)}
$$


Selanjutnya disubstitusikan semua nilai parameter dari hasil estimasi ke $R_{0}$ yang telah diperoleh seperti pada Persamaan (4) dan didapatkan nilai $R_{0}=3.2562$. Hal ini berarti dengan nilai parameter-parameter yang dihasilkan dari hasil estimasi parameter menunjukkan bahwa masih ada penyebaran COVID-19 di Indonesia.

\section{Simulasi}

Pada bagian ini akan disimulasikan model matematika dengan memperhatikan faktor migrasi terinfeksi untuk kasus penyebaran COVID-19 di Indonesia dengan menggunakan nilai parameterparameter yang diperoleh dari hasil estimasi parameter. Simulasi dilakukan dengan tujuan untuk mengetahui dinamika perkembangan kasus harian positif COVID-19 yang terjadi di Indonesia. Nilai awal yang digunakan adalah jumlah kasus pada tanggal 15 April 2020 dari setiap variabel $(S, E, A, R)$ yaitu 269.813.254, 181.164, 5.136, dan 446.

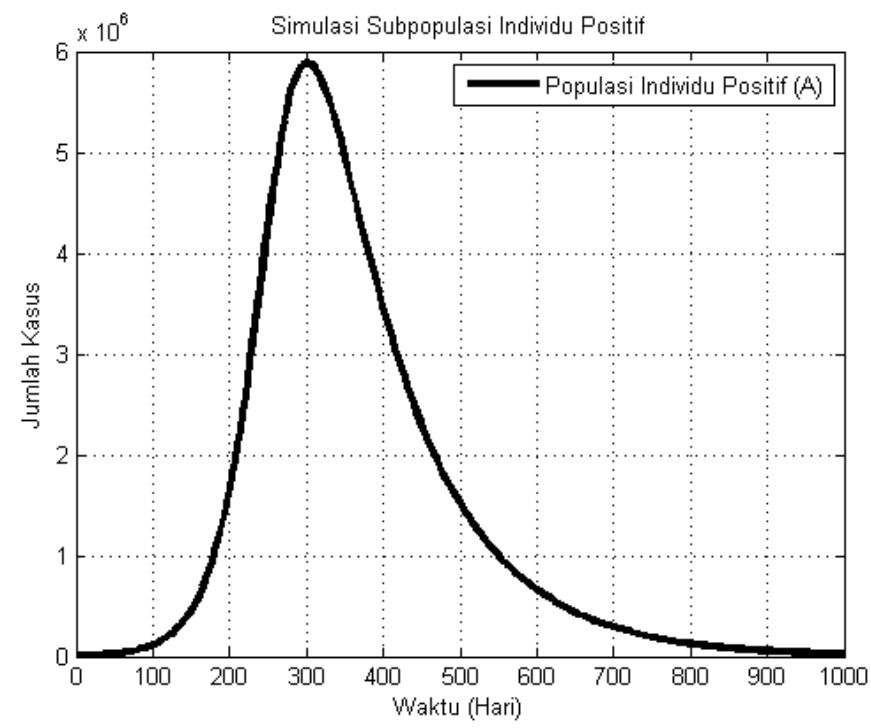

Gambar 3. Prediksi Pertambahan Kasus Harian Positif COVID-19 di Indonesia

Pada Gambar 3 terlihat bahwa jumlah kasus harian positifCOVID-19 di Indonesia terus mengalami peningkatan hingga pada hari ke-300 pengamatan. Dengan awal pengamatan tertanggal 15 April 2020 maka dapat disimpulkan bahwa prediksi puncak pandemi COVID-19 di Indonesia akan terjadi pada tanggal 09 Februari 2021. Dari Gambar 3 juga disimpulkan bahwa setelah mengalami puncak pandemi pada tanggal 09 Februari 2021, akan diperlukan waktu yang cukup lama untuk masa pemulihan hingga pada hari terakhir pengamatan yaitu tertanggal 10 Januari 2023.

Selanjutnya, untuk mengetahui lebih jauh lagi besar pengaruh faktor migrasi yang terinfeksi terhadap peningkatan kasus harian positif COVID-19 di Indonesia, maka akan dilakukan dua kali simulasi dengan mengubah nilai parameter $p$ pada model matematika di persamaan ke-1, yaitu ketika gelombang migrasi 
rendah $(p<1)$ dan ketika gelombang migrasi tinggi $(p>1)$. Keadaan seperti pada model matematika di persamaan ke-2, dianggap sebagai kondisi normal dan dinamikanya dapat dilihat pada Gambar 3.

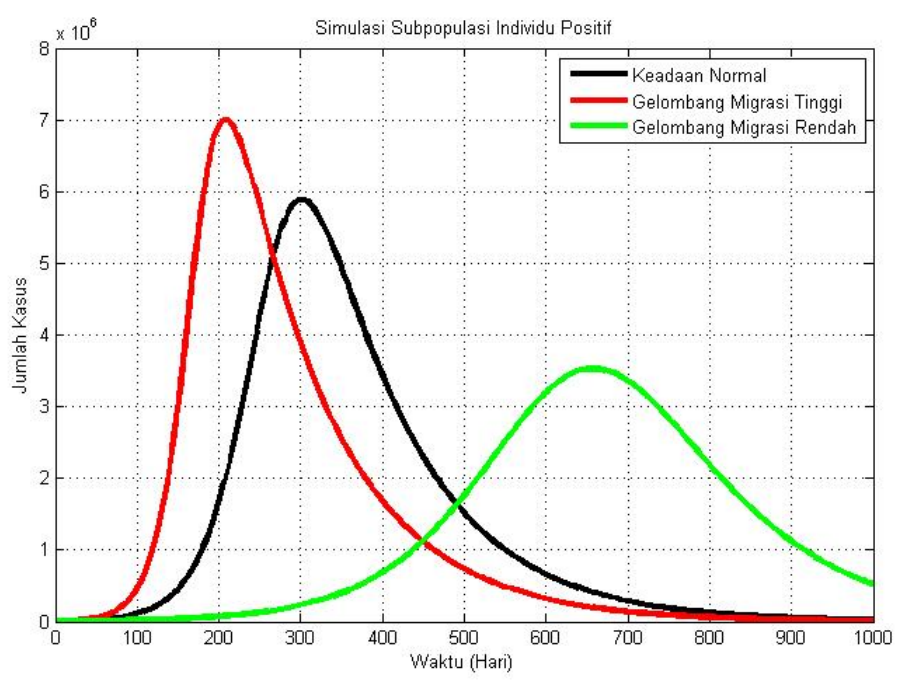

Gambar 4. Prediksi Kasus Harian Positif COVID-19 di Indonesia dengan Tiga Kondisi Berbeda

Dari Gambar 4 terlihat bahwa ketika terjadi gelombang migrasi tinggi $(p>1)$, puncak pandemik COVID-19 mengalami peningkatan sehingga kurva yang terbentuk lebih lancip dan tinggi. Dengan demikian, masa pemulihan pada keadaan ini terjadi lebih lama dibandingkan pada keadaan normal. Hal ini mungkin saja terjadi karena kapasitas dari fasilitas dan tenaga medis yang tidak memadai untuk menangani kasus yang terlampau banyak diatas kapasitas normal yang mampu untuk ditanggung. Berikutnya, ketika terjadi gelombang migrasi rendah $(p<1)$, puncak pandemik COVID-19 mengalami penurunan sehingga kurva yang terbentuk lebih tumpul dan rendah. Dari sini, durasi masa pemulihan dari puncak pandemi terjadi lebih sebentar dibandingkan pada keadaan normal. Oleh karena itu, pada keadaan ini jika terjadi penambahan kasus baru maka langkah penangan bisa dilakukan lebih baik dan optimal.

Dari simulasi tersebut dapat disimpulkan bahwa faktor migrasi memberikan pengaruh yang signifikan terhadap penyebaran kasus COVID-19 di Indonesia, yang membuat semakin parahnya pandemi ini berlangsung.

\section{Simpulan}

Pada paper ini telah diformulasikan model matematika SEAR dengan memperhatikan faktor migrasi terinfeksi untuk memprediksi kasus COVID-19 di Indonesia. Berikutnya dilakukan estimasi parameter menggunakan algoritma genetika dari model matematika SEAR menggunakan data kasus COVID-19 di Indonesia. Berdasarkan hasil estimasi parameter diperoleh nilai perhitungan basic reproduction number $\left(R_{0}\right)$ sebesar $R_{0}=3.2562$. Hal ini menunjukkan bahwa masih terjadi endemik kasus penyebaran 
COVID-19 di Indonesia. Selanjutnya, dari hasil simulasi numerik dapat diprediksi puncak pandemi COVID-19 di Indonesia akan terjadi sekitar bulan Februari 2021. Setelah mengalami puncak pandemi akan diperlukan waktu yang cukup lama untuk masa pemulihan yakni sekitar bulan Januari 2023. Selain itu juga dapat ditunjukkan bahwa faktor migrasi memberikan pengaruh yang signifikan terhadap penyebaran kasus COVID-19 di Indonesia. Semakin besar faktor migrasi yang terjadi maka semakin lancip dan tinggi kurva dari penyebaran kasus COVID-19 di Indonesia sehingga membuat semakin parahnya pandemi ini berlangsung.

\section{Daftar Pustaka}

[1] Kementerian Kesehatan Indonesia, “Apakah Coronavirus dan COVID-19 itu?,” Aug. 2020. https://infeksiemerging.kemkes.go.id/uncategorized/qna-pertanyaan-dan-jawaban-terkaitcovid-19 (accessed Aug. 25, 2020).

[2] Kementerian Kesehatan Indonesia, "Situasi Terkini Perkembangan Novel Coronavirus (Covid-19)," May 28, 2020. https://infeksiemerging.kemkes.go.id/situasi-infeksiemerging/situasi-terkini-perkembangan-coronavirus-disease-covid-19-28-mei-2020 (accessed Aug. 25, 2020).

[3] Detik.com, "JK Soroti Protokol Kesehatan yang Tiap Hari Dilanggar, Ini Respons Pemerintah," May 21, 2020. https://news.detik.com/berita/d-5023223/jk-soroti-protokolkesehatan-yang-tiap-hari-dilanggar-ini-respons-pemerintah (accessed Sep. 13, 2020).

[4] Pusat Penelitian Kependudukan (LIPI), "Kajian LIPI: Di Tengah Pandemi Covid-19, Ribuan Orang Tetap Akan Mudik Lebaran.," Apr. 15, 2020. https://kependudukan.lipi.go.id/liputan-media/kajian-lipi-di-tengah-pandemi-covid-19ribuan-orang-tetap-akan-mudik-lebaran/ (accessed Jun. 13, 2020).

[5] Merdeka.com, "591 Pekerja Migran Tiba di Jakarta \& Bali Positif Terpapar Covid-19," May 18, 2020. https://www.merdeka.com/peristiwa/591-pekerja-migran-tiba-di-jakartabali-positif-terpapar-covid-19.html (accessed Jun. 13, 2021).

[6] N. Nuraini, K. Khairudin, and M. Apri, "Modeling Simulation of COVID-19 in Indonesia based on Early Endemic Data," Communication in Biomathematical Sciences, vol. 3, no. 1, Apr. 2020, doi: 10.5614/cbms.2020.3.1.1.

[7] H. Susanto, "Kalau kita tidak serius, puncak COVID-19 di Indonesia bisa sekitar 2 bulan lagi, di bulan Ramadan,” Mar. 2020. Accessed: Mar. 17, 2020. [Online]. Available: http://hadisusanto.net/paper2/covid19.pdf 
[8] D. Aldila, "Analyzing the impact of the media campaign and rapid testing for COVID-19 as an optimal control problem in East Java, Indonesia," Chaos, Solitons \& Fractals, vol. 141, Dec. 2020, doi: 10.1016/j.chaos.2020.110364.

[9] D. Aldila, B. M. Samiadji, G. M. Simorangkir, S. H. A. Khosnaw, and M. Shahzad, "Impact of early detection and vaccination strategy in COVID-19 eradication program in Jakarta, Indonesia,” BMC Research Notes, vol. 14, no. 1, Dec. 2021, doi: 10.1186/s13104-02105540-9.

[10] H. N. Fadhilah, E. Apriliani, and D. K. Arif, "Prediksi Penyebaran Covid-19 di Indonesia dan Jawa Timur dengan Metode Extended Kalman Filter," Limits: Journal of Mathematics and Its Applications, vol. 18, no. 1, p. 1, Mar. 2021, doi: 10.12962/limits.v18i1.6933.

[11] W. Wang, J. Xin, and F. Zhang, "Persistence of an SEIR Model with Immigration Dependent on the Prevalence of Infection," Discrete Dynamics in Nature and Society, vol. 2010, 2010, doi: 10.1155/2010/727168.

[12] Badan Pusat Statistik, "Umur Harapan Hidup Saat Lahir (UHH) Menurut Provinsi [Metode Baru], 2010-2019,” $\quad$ Apr. 2018. https:/www.bps.go.id/dynamictable/2018/04/16/1298/angka-harapan-hidup-saat-lahirmenurut-provinsi-2010-2017.html (accessed May 30, 2020).

[13] R. L. Haupt and S. E. Haupt, PRACTICAL GENETIC ALGORITHMS SECOND EDITION. 2004.

[14] Windarto, S. W. Indratno, N. Nuraini, and E. Soewono, "A comparison of binary and continuous genetic algorithm in parameter estimation of a logistic growth model," in AIP Conference Proceedings, 2014, pp. 139-42.1587. doi: 10.1063/1.4866550.

[15] P. van den Driessche and J. Watmough, "Reproduction numbers and sub-threshold endemic equilibria for compartmental models of disease transmission," Mathematical Biosciences, vol. 180, no. 1-2, Nov. 2002, doi: 10.1016/S0025-5564(02)00108-6. 